\title{
POLA KONSUMSI SUMBER PURIN, AKTIVITAS FISIK, DAN STATUS GIZI DENGAN KADAR ASAM URAT PADA LANSIA DI PUSKESMAS KECAMATAN MAKASAR JAKARTA
}

\author{
Purine-Rich Foods, Nutritional Status, Physical Activity and \\ Prevalence Of Hyperuricaemia In Pre-Elderly and Elderly in \\ Makasar Health Center Jakarta \\ Gina Ganda Fitriana ${ }^{1}$, Adhila Fayasari ${ }^{1}$ \\ ${ }^{11}$ Program Studi S1 Gizi, Fakultas Kesehatan Masyarakat, Universitas Binawan; \\ d.fayasari@gmail.com
}

\begin{abstract}
Degenerative processes can decrease the endurance in elderly that leads to health problems such as gout. Gout is a metabolic disorder, which is indicated by an increase in uric acid in bloodstream (hyperuricemia). Factors affecting a high level of uric acid are purine intake, physical activity, and nutritional status. This study aimed to analyze the relationship between consumption patterns of purine source food, nutritional status, and physical activity with the uric acid level in the elderly. The study design was cross-sectional. The sample consisted of 100 subjects at Puskesmas Kecamatan Makasar. The analytical used chi-square. Patterns of food consumption of purine sources were measured using FFQ questionnaires which were then cut off into 2 categories: lowmoderate purine category with score $<55$ and high purine category with a score of $\geq 55$ physical activity and nutritional status were measured using questionnaires, uric acid levels was obtained by looking at laboratory results or from patients' medical records. There were $10 \%$ of subjects withmoderate uric acid levels and $90 \%$ of subjects with high purine consumption patterns. Based on the results of the chi-square test there was a significant difference $(p<0.05)$ between the consumption pattern of purine source food with normal uric acid and high uric acid. There was a relationship between the consumption pattern of purine food source with the uric acid level in the elderly.
\end{abstract}

Keywords: purine-rich foods, physical activity, nutritional status, uric acid, elderly.

\begin{abstract}
ABSTRAK
Proses degeneratif dapat menurunkan ketahanan tubuh pada lansia yang akan menimbulkan keluhan kesehatan termasuk penyakit asam urat. Asam urat atau gout merupakan gangguan metabolik tubuh yang ditandai dengan meningkatkan kadar asam urat (hiperurisemia). Beberapa faktor yang dapat mempengaruhi kadar asam urat diantaranya pola konsumsi purin, aktivitas fisik dan status gizi. Penelitian ini bertujuan menganalisis hubungan antara pola konsumsi pangan sumber purin, status gizi dan aktivitas fisik dengan kadar asam urat pada lansia. Desain studi ini cross sectional pada pralansia dan lansia sebanyak100 subyek di Puskesmas Kecamatan Makasar. Pola konsumsi pangan sumber purin diukur dengan kuisioner SQ-FFQ berisi makanan tinggi purin, kemudian diskoring dan dikategorikan menjadi 2 kategori yaitu kategori purin rendah-sedang dengan skor <55 dan kategori purin dengan skor $\geq 55$, selain itu aktivitas fisik dan status gizi diukur dengan teknik wawancara menggunakan kuisioner sedangkan kadar asam urat dengan melihat hasil laboratorium atau dari rekam medik pasien. Analisis data dilakukan analisis chi square. Sebanyak 90\% subyek dengan pola konsumsi purin tinggi. Terdapat hubungan yang signifikan $(\mathrm{p}<0,05)$ antara pola konsumsi pangan sumber purin dengan kadar asam urat normal dan asam urat tinggi. Terdapat hubungan antara pola konsumsi pangan sumber purin dengan kadar asam urat pada lansia.
\end{abstract}

Kata kunci: konsumsi sumber purin, status gizi, aktivitas fisik, asam urat, lansia 


\section{PENDAHULUAN}

\begin{tabular}{lrr}
\multicolumn{1}{c}{ Jumlah lansia di } & Indonesia \\
semakin & bertambah & dengan \\
peningkatan & kondisi & sosial \\
masyarakat yang semakin & membaik
\end{tabular}
dan usia harapan hidup (UHH) makin meningkat (Kemenkes, 2014). Pada tahun 2000 UHH di Indonesia adalah 64,5 tahun (dengan persentase populasi lansia adalah 7,18\%). Angka ini meningkat menjadi 69,43 tahun pada tahun 2010 (dengan persentase populasi lansia sebanyak 7,56\%) dan pada tahun 2011 menjadi 69,65 tahun (dengan persentase populasi lansia sebanyak 7,58\%) (Kemenkes, 2013a).

Masalah kesehatan pada lansia didominasi oleh penyakit tidak menular, antara lain tekanan darah tinggi, gout atau artritis, kardiovaskuler, endokrin dan neoplasma (Shahar et al., 2007). Di Indonesia, arthritis pirai (asam urat) menduduki urutan kedua setelah osteoarthritis. Prevalensi arthritis pirai di Indonesia diperkirakan 1,6 $13,6 / 100.000$ orang, prevalensi ini meningkat seiring dengan meningkatnya umur (Djokroprawiro, 2007).

Menurut Riskesdas tahun 2013, terdapat 22 provinsi dengan penduduk aktivitas fisik tergolong kurang aktif berada diatas rata-rata Indonesia. Lima tertinggi adalah provinsi penduduk DKI Jakarta (44,2\%), Papua (38,9\%), Papua Barat (37,8\%), Sulawesi Tenggara dan Aceh (masing-masing 37,2\%) (Kemenkes, 2013b)
Faktor resiko yang menyebabkan orang terserang penyakit asam urat adalah genetik atau riwayat keluarga, asupan senyawa purin berlebihan, konsumsi alkohol berlebih, kegemukan (obesitas), hipertensi dan penyakit jantung, obat-obatan tertentu (terutama diuretika), dan gangguan fungsi ginjal (Vitahealth, 2004; Silviana et al., 2015; Rosdiana et al, 2018; Diantari \& Candra, 2013). Adapun penelitian lain yang menyebutkan penyebab yang mempengaruhi kadar asam urat adalah olah raga dan aktivitas fisik (Pursriningsih \& Panunggal, 2015; Fauzi, 2018).

Pada wanita, peningkatan risiko penyakit asam urat dimulai sejak memasuki masa menopause, dikarenakan hormon estrogen wanita sudah tidak diproduksi lagi, sehingga menurunkan ekskresi asam urat (Moriwaki, 2014; Arpiana, 2017) Berdasarkan kelompok umur terdapat kecenderungan semakin bertambah umur proporsi tersebut mulai meningkat pada umur $\geq 50$ tahun ke atas (Muhajir et al, 2014)

Rata-rata proporsi perilaku sedentari $\geq 6$ jam merupakan kelompok umur 60 - 64 tahun secara nasional sebesar 26,9\% dan kelompok umur $65+$ tahun sebesar $37,4 \%$ (Riskesdas, 2013). Proporsi perilaku sedentari $\geq 6$ jam lebih berisiko kejadian sindrom metabolic, dan penyakit tidak menular lainnya (Yusfita, 2019). Adapun aktivitas yang berlebih (intensitas tinggi) berkorelasi positif terhadap kadar 
asam urat pada populasi yang mengalami sindom metabolik (Dayana \& Dahrudin, 2015)

Berdasarkan hasil cakupan pelayanan yang diberikan pemerintah kepada pra lansia dan lansia di Provinsi DKI Jakarta sebesar 45,37\% dari seluruh penduduk di wilayah Provinsi DKI Jakarta, sedangkan untuk cakupan di wilayah Jakarta Timur sebesar $32,34 \%$. Berdasarkan data tersebut, wilayah Jakarta Timur merupakan daerah yang menempati posisi kedua terendah setelah Jakarta Barat untuk cakupan pelayanan kesehatan pada pra lansia dan lansia (Sudinkes DKI Jakarta Timur, 2017).

\section{METODE}

Desain yang digunakan pada penelitian ini adalah cross sectional pada pra lansia 46 tahun - 59 tahun dan lansia $\geq 60$ tahun. Penelitian dilakukan pada bulan April - Mei 2018 yang bertempat di wilayah kerja Puskesmas Kecamatan Makasar, Jakarta Timur. Penelitian ini telah mendapat persetujuan dari Komisi Etik Fakultas Kedokteran Universitas Indonesia dengan nomor etik: 0484/UN2.F1/ETIK/2018.

Populasi adalah semua pasien lansia ( $\geq 46$ tahun) yang berkunjung di Puskesmas Kecamatan Makasar dengan perhitungan jumlah sampel minimal adalah 96 subyek, namun dalam penelitian ini yang memenuhi kriteria adalah 100 subyek. Adapun kriteria inklusi dalam penelitian ini yaitu 1) Penduduk berusia $\geq 46$ tahun dengan status kadar asam urat tinggi, 2) Pra-lansia dan lansia yang mengerti
Bahasa Indonesia, 3) Pra-lansia dan lansia yang datang ke posyandu lansia, dan 4) Pra-lansia dan lansia yang mampu berkomunikasi secara verbal.

Data karakteristik subyek diambil dengan menggunakan kuisioner melalui teknik wawancara yaitu usia, jenis kelamin, pendidikan dan pekerjaan. Asupan sumber purin diukur menggunakan FFQ (Food Frequency Questionnaire) yang berisi 22 item makanan yang dibagi menjadi 3 kelompok kandungan purin tinggi, sedang, dan rendah (Tabel 1). Pengelompokan bahan makanan menurut kadar purin dikatakan tinggi jika kadar purin 100 - 1000 mg purin/100 g bahan makanan (Almatsier, 2010).

Skoring diberikan sesuai dengan frekuensi konsumsi; semakin tinggi frekuensi konsumsinya, maka semakin tinggi nilainya $(>1 \mathrm{kali} / \mathrm{hr}$ diberi skor 5, $1 \mathrm{kali} / \mathrm{hr}$ diberi skor 4, 4-6 kali/mg diberi skor 3, 1-3 kali/mg diberi skor 2, 1-3 kali/bln diberi skor1, tidak pernah diberi skor 0). Total skor dijumlahkan, dikategorikan menjadi 2 kategori yaitu kategori purin rendah-sedang (< $100 \mathrm{mg} / 100 \mathrm{~g}$ bahan makanan) dengan skor $<55$, dan kategori purin tinggi $(>100 \mathrm{mg} / 100 \mathrm{~g}$ bahan makanan) dengan skor $\geq 55$.

Data aktivitas fisik diukur dengan me-recall kegiatan selama 24 jam aktivitas fisik yang dilakukan dan dinyatakan dalam Physical Activity Level (PAL) atau tingkat aktivitas fisik. PAL merupakan besarnya energi yang dikeluarkan (kkal) per 
kilogram berat badan, kemudian dilakukan skoring untuk tiap kegiatan sesuai dengan Physical Activity Ratio (PAR) (jumlah energi yang dikeluarkan untuk jenis aktivitas per satuan waktu tertentu). Hasil penjumlahan dibagi menjadi 2 kategori, yaitu kategori aktivitas ringan apabila nilai $\mathrm{PAL} \leq 1,69$ dan kategori aktivitas sedang-berat apabila nilai $\mathrm{PAL} \geq 1,70$.

Tabel 1. Pengelompokan Bahan Makanan Menurut Kadar Purin dan Anjuran Makan

\begin{tabular}{|c|c|c|}
\hline Kelompok Kandungan Purin & Ajuran Makan & Bahan Makanan \\
\hline $\begin{array}{l}\text { Kelompok 1: } \\
\text { Kandungan Tinggi Purin }(100- \\
1000 \text { mg Purin/100g Bahan } \\
\text { Makanan) }\end{array}$ & Sebaiknya dihindari & $\begin{array}{l}\text { Otak, hati, jantung, ginjal, } \\
\text { jeroan, ekstrak daging/kaldu, } \\
\text { bouillon, bebek, ikan sarden, } \\
\text { makarel, kerang }\end{array}$ \\
\hline $\begin{array}{l}\text { Kelompok } 2 \text { : Kandungan Purin } \\
\text { Sedang }(9-100 \mathrm{mg} \text { Purin/100g } \\
\text { Bahan Makanan) }\end{array}$ & $\begin{array}{l}\text { Dibatasi, maksimal : } \\
-50-75 \text { gram } \\
(1-11 / 2 \text { ptg }) \\
\text { daging, ikan atau } \\
\text { unggas } \\
-\quad 100 \text { gram } \\
(1 \quad \text { mangkok) } \\
\text { sayuran per hari }\end{array}$ & $\begin{array}{l}\text { Daging sapi, ikan atau unggas, } \\
\text { ayam, udang, kacang kering } \\
\text { dan olahannya (tahu tempe), } \\
\text { asparagus, bayam, daun } \\
\text { singkong, kangkung, daun dan } \\
\text { biji melinjo }\end{array}$ \\
\hline $\begin{array}{l}\text { Kelompok } 3 \text { : Kandungan Purin } \\
\text { Rendah (dapat diabaikan) }\end{array}$ & $\begin{array}{l}\text { Dapat di makan setiap } \\
\text { hari }\end{array}$ & $\begin{array}{l}\text { Nasi, ubi, singkong, jagung, } \\
\text { roti, mie, bihun, tepung beras, } \\
\text { pudding, cake, kue keirng, } \\
\text { susu, keju, telur, lemak dan } \\
\text { minyak, gula, sayuran } \\
\text { (kecuali,sayuran kelompok 2), } \\
\text { buah-buahan. }\end{array}$ \\
\hline
\end{tabular}

Sumber : Almatsier (2010)

Data status gizi yang diperoleh melalui pengukuran berat badan dengan menggunakan timbangan digital CAMRY EB9003 dengan ketelitian $0,1 \mathrm{~kg}$ dan kapasitas maksimal berat $150 \mathrm{~kg}$, dan pengukuran tinggi badan menggunakan microtoise MT-701 dengan maksimal pengukuran 200 $\mathrm{cm}$, kemudian dikategorikan menjadi 2 kategori yaitu status gizi kurangnormal (IMT $\leq 22,9 \mathrm{~kg} / \mathrm{m}^{2}$ dan status gizi lebih (IMT $\geq 23,0 \mathrm{~kg} / \mathrm{m}^{2}$ ).
Data kadar asam urat diambil melalui data sekunder yang dilihat dari rekam medis Laboratorium Puskesmas Kecamatan Makasar. Nilai pengukuran maksimal 2 minggu terakhir. Kadar asam urat menurut Sutanto (2013) dikategorikan menjadi dua yaitu normal $(2,4-6 \mathrm{mg} / \mathrm{dL})$ dan tinggi (>6 mg/dL).

\section{Analisis Data}

Data yang diperoleh dianalisis menggunakan program statistik, ChiSquare pada taraf kepercayaan 95\% 
$(0,05)$ sehingga dapat diketahui ada tidaknya hubungan yang bermakna secara statistik.

\section{HASIL DAN PEMBAHASAN}

Karakteristik jenis kelamin subyek terbanyak yaitu perempuan sebanyak 73 orang (73\%), dibandingkan dengan subyek yang berjenis kelamin laki-laki sebanyak 27 orang $(27 \%)$. Karakteristik usia sebagian besar subyek merupakan kelompok usia lanjut dini atau prasenium yang berusia 56 - 65 tahun sebanyak 42 orang (42\%), dibandingkan dengan subyek yang berusia $>65$ tahun hanya sebanyak 18 orang (18\%) yang mana usia ini merupakan kelompok manusia usia lanjut atau manula.

Karakteristik tingkat pendidikan lansia menunjukkan bahwa lebih banyak lansia yang berpendidikan SMP sebanyak 35 orang $(35 \%)$ dan yang lebih sedikit yaitu lansia dengan berpendidikan Perguruan Tinggi sebanyak 1 orang (1\%). Berdasarkan jenis pekerjaan lansia menunjukkan bahwa subyek yang bekerja sebagai ibu rumah tangga (IRT) lebih banyak yaitu 65 orang dan paling sedikit yaitu lansia tidak bekerja, bekerja sebagai Pegawai Negeri Sipil (PNS) dan lainlain (Tukang Ojek) dengan masingmasing sebanyak 1 orang (1\%) (Tabel $2)$.

Tabel 2. Distribusi Frekuensi Berdasarkan jenis kelamin, Usia, pendidikan, dan pekerjaan di Puskesmas Kecamatan Makasar

\begin{tabular}{lcc}
\hline \multicolumn{1}{c}{ Variabel Karakteristik } & n & $(\%)$ \\
\hline Jenis Kelamin & & \\
Laki-laki & 27 & 27 \\
Perempuan & 73 & 73 \\
Usia & & \\
Lansia Awal (46-55 Tahun) & 40 & 40 \\
Lansia dini (56-65 Tahun) & 42 & 42 \\
Lansia/ Manula (>65 Tahun) & 18 & 18 \\
Pendidikan & & \\
Tidak Sekolah & 6 & 6 \\
SD & 34 & 34 \\
SMP & 35 & 35 \\
SMA & 24 & 24 \\
Perguruan Tinggi & 1 & 1 \\
Pekerjaan & & \\
Tidak Bekerja & 1 & 1 \\
IRT & 65 & 65 \\
Buruh & 10 & 10 \\
Wiraswasta & 9 & 9 \\
PNS & 1 & 1 \\
Lain-lain & 1 & 1 \\
Pensiunan & 13 & 13 \\
\hline
\end{tabular}


Berdasarkan pola konsumsinya, sebagian besar subyek mempunyai pola konsumsi pangan sumber purin tinggi sebanyak 90 orang (90\%), sedangkan subyek yang mempunyai pola konsumsi pangan sumber purin normal sebanyak 10 orang (10\%) (Tabel 3).Aktivitas fisik subyek dengan kategori ringan sebanyak 91 orang $(91 \%)$, sedangkan subyek yang memiliki aktivitas fisik sedang-tinggi hanya sebanyak 9 orang (9\%). Status gizi subyek menunjukkan bahwa sebagian besar subyek mempunyai status gizi lebih sebanyak 68 orang (68\%), dibandingkan dengan subyek yang memiliki status gizi kurangnormal sebanyak 32 orang (32\%) .

Subyek yang memiliki kadar asam urat dengan katagori tinggi sebanyak 61 orang (61\%) lebih banyak dibandingkan dengan subyek dengan kadar asam urat normal sebanyak 39 orang (39\%) (Tabel 3).

Tabel 3. Distribusi Pola Konsumsi Pangan Sumber Purin, Aktivitas Fisik, Status Gizi, dan Kadar Asam Urat di Puskesmas Kecamatan Makasar

\begin{tabular}{lcc}
\hline \multicolumn{1}{c}{ Variabel } & n & $(\boldsymbol{\%})$ \\
\hline Konsumsi sumber purin & & \\
Rendah - Sedang (<100mg/ 100g bahan makanan) & 10 & 10 \\
Tinggi ( $\geq 100 \mathrm{mg} /$ 100g bahan makanan) & 90 & 90 \\
Aktivitas fisik & & \\
$\quad$ Ringan $(P A L \leq 1,6)$ & 91 & 91 \\
$\quad$ Sedang - Berat $(P A L \geq 1,7)$ & 9 & 9 \\
Status Gizi & & \\
$\quad$ Kurang - Normal $\left(\mathrm{IMT} \leq 22,9 \mathrm{~kg} / \mathrm{m}^{2}\right)$ & 32 & 32 \\
Lebih (IMT $\left.\geq 23,0 \mathrm{~kg} / \mathrm{m}^{2}\right)$ & 68 & 68 \\
Asam Urat & & \\
$\quad$ Normal $(<6 \mathrm{mg} / \mathrm{dL})$ & 39 & 39 \\
Tinggi $(>6 \mathrm{mg} / \mathrm{dL})$ & 61 & 61 \\
\hline
\end{tabular}

Berikut Tabel 4 memaparkan adanya perbedaan proporsi antara variabel kadar asam urat tinggi pada lansia dengan pola konsumsi pangan sumber purin rendah-sedang (10\%) dan pola konsumsi pangan sumber purin tinggi $(66,67 \%)$. Hasil uji statistik menyatakan adanya hubungan antara pola konsumsi pangan sumber purin dengan kadar asam urat pada lansia dengan nilai $p$
$<0,05$ yaitu $p$ value 0,001 yang berarti Ha diterima. Adanya hubungan antara

pola konsumsi pangan sumber purin dengan kadar asam urat pada lansia sejalan dengan peneltian Pursriningsih (2014) yang menunjukan bahwa ada hubungan antara konsumsi purin dengan kadar asam urat. 
Tingkat aktivitas subyek yang ringan mempunyai kadar asam urat tinggi sebesar $63,74 \%$ lebih tinggi dibandingkan dengan subyek dengan kadar asam urat normal sebesar $36,26 \%$. Sedangkan, subyek dengan aktivitas yang sedang-berat mempunyai kadar asam urat tinggi sebesar 33,33\% lebih rendah dibandingkan dengan kadar asam urat normal sebesar $66,67 \%$. Hasil uji chi square menunjukkan tidak terdapat hubungan yang signifikan antara aktivitas fisik dengan kadar asam urat pada lansia $(\mathrm{p}=0,148)$. Temuan ini sejalan dengan penelitian sebelumnya oleh Nursilmi (2013) yang menunjukkan tidak terdapat hubungan yang signifikan antara aktivitas fisik dengan kadar asam urat pada lansia wanita.
Aktivitas yang dilakukan oleh manusia erat kaitanya dengan kadar asam urat yang terdapat dalam darah (Nursilmi, 2013). Aktivitas yang berat dapat memperberat penyakit gout atau penyakit asam urat yang ditandai dengan peningkatan kadar asam urat dalam darah, dan menunjukan hasil yang tidak linear antara aktivitas fisik dengan kadar asam urat. Adapun hasil tersebut juga dipengaruhi oleh komposisi otot dan kemampuan motorik dari individu (Beavers et al, 2014). Meningkatnya kadar asam laktat dalam darah menyebabkan penurunan ekskresi asam urat, sehingga kandungan asam urat dalam tubuh meningkat (Williams, 2014)

Tabel 4. Hubungan Pola Konsumsi Pangan Sumber Purin, Aktivitas Fisik dan Status Gizi dengan Kadar Asam Urat di Puskesmas Kecamatan Makasar

Kadar Asam Urat

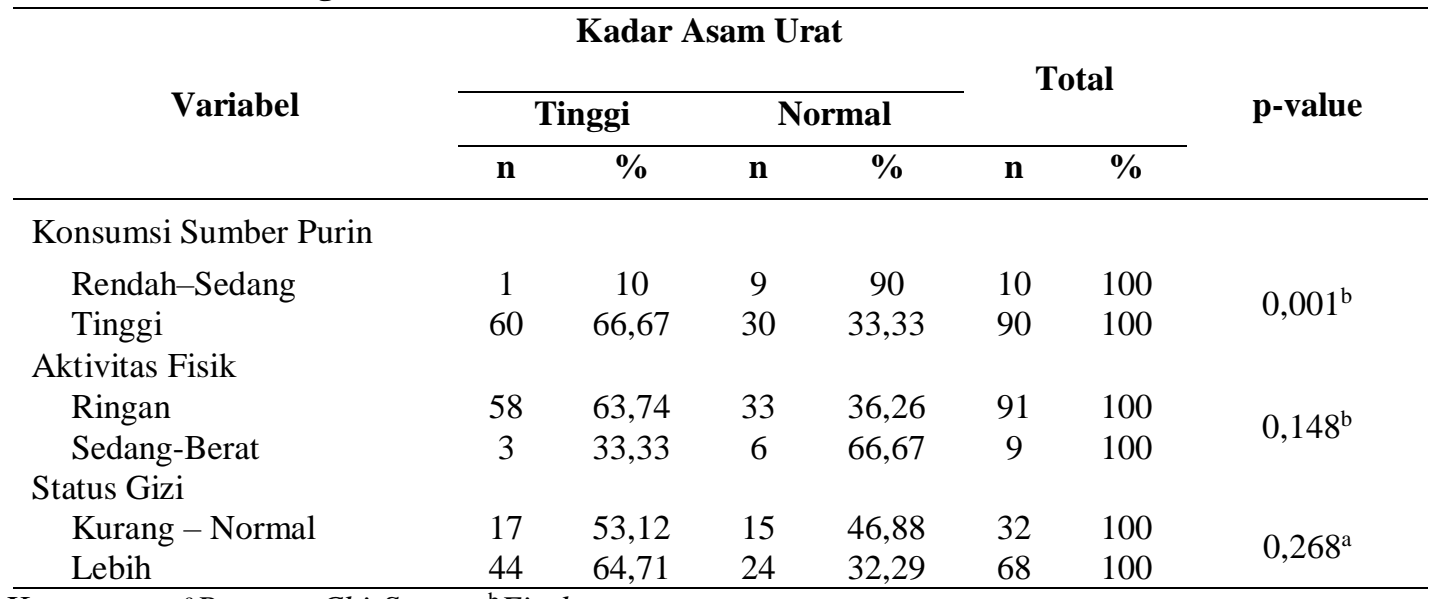

Keterangan : Pearson Chi-Square ${ }^{\mathrm{b}}$ Fischer exact test

Tabel 4 menjelaskan bahwa ada perbedaan proporsi antara variabel kadar asam urat tinggi pada lansia dengan status gizi kurang-normal
$(53,12 \%)$ dan status gizi lebih $(64,71 \%)$. Namun, hasil uji statistik menyatakan tidak terdapat hubungan yang signifikan antara indeks massa 
tubuh (IMT) dengan kadar asam urat, dimana diketahui untuk nilai $\mathrm{p}>0,05$. Hal ini sejalan dengan penelitian Winarni (2016) yang menyatakan bahwa tidak terdapat hubungan antara IMT dengan kadar asam urat dalam darah lansia. Hal ini juga dapat terjadi akibat dari faktor lain yang mempengaruhi seperti, makanan tinggi purin, umur, jenis kelamin, dan adanya variabel pengganggu lainnya yang masih tidak dapat dikendalikan (Winarni, 2016). Penyebab kadar asam urat dalam darah yang tinggi juga dapat disebabkan oleh kelainan enzim dan kelainan molekuler yang tidak jelas. Secara umum 80-90\% kasus peningkatan asam urat disebabkan gangguan ekskresi asam urat dan 10-20\% disebabkan peningkatan produksi asam urat (Lingga, 2012).

Analisis stratifikasi hubungan pola konsumsi pangan sumber purin dengan kadar asam urat pada pralansia dan lansia dilakukan untuk menganalisis hubungan suatu variabel dependent (kadar asam urat) dengan akibatnya dalam kelompok usia (pra-lansia dan lansia) yang lebih homogen atau strata berdasarkan tingkat variabel confounding-nya, yang dibuktikan dengan uji strata.

Tabel 5. Analisis Stratifikasi Hubungan Pola Konsumsi Pangan Sumber Purin dengan Kadar Asam Urat pada Pra-lansia dan Lansia

\begin{tabular}{|c|c|c|c|c|c|c|c|c|}
\hline \multirow{3}{*}{$\begin{array}{c}\text { Karakteristik } \\
\text { Usia }\end{array}$} & \multirow{3}{*}{ Pola Konsumsi } & \multicolumn{4}{|c|}{ Kadar Asam Urat } & & & \multirow{3}{*}{$\begin{array}{c}P \text { - } \\
\text { value }\end{array}$} \\
\hline & & \multicolumn{2}{|c|}{ Tinggi } & \multicolumn{2}{|c|}{ Normal } & \multicolumn{2}{|c|}{ Total } & \\
\hline & & $\mathbf{N}$ & $\%$ & $\mathbf{n}$ & $\%$ & $\mathbf{N}$ & $\%$ & \\
\hline \multirow[t]{2}{*}{ Pra-lansia } & Purin Tinggi & 0 & 0 & 4 & 4 & 4 & 100 & \multirow{2}{*}{$0,014^{*}$} \\
\hline & Purin Rendah-Sedang & 33 & 68,75 & 15 & 31,25 & 48 & 100 & \\
\hline \multirow[t]{2}{*}{ Lansia } & Purin Tinggi & 1 & 16,67 & 5 & 83,33 & 6 & 100 & \multirow{2}{*}{$0,069^{*}$} \\
\hline & Purin Rendah-Sedang & 27 & 64,29 & 15 & 35,71 & 42 & 100 & \\
\hline
\end{tabular}

Keterangan : ${ }^{*}$ Fischer exact test

Jumlah pra-lansia yang mengkonsumsi purin tinggi mempunyai kadar asam urat tinggi $(0 \%)$ lebih rendah dibandingkan dengan kadar asam urat normal (4\%), sedangkan pra-lansia yang mengkonsumsi purin rendah-sedang mempunyai kadar asam urat tinggi $(68,75 \%)$ lebih tinggi dibandingkan dengan kadar asam urat normal $(31,25 \%)$. Jumlah lansia yang mengkonsumsi pangan sumber purin tinggi $(16,67 \%)$ lebih rendah dibandingkan dengan kadar asam urat normal $(83,33 \%)$, sedangkan lansia yang memiliki kadar asam urat 
rendah-sedang $(64,29 \%)$ lebih tinggi dibandingkan dengan kadar asam urat normal $(35,71 \%)$.

\section{KESIMPULAN}

Subyek didominasi oleh kelompok pra-lansia yaitu sebanyak 52 orang (52\%), sedangkan lansia sebanyak 48 orang (48\%). Pola konsumsi pangan sumber purin tinggi sebanyak 90 orang (90\%). Aktivitas fisik subyek dengan kategori ringan sebanyak 91 orang (91\%) lebih tinggi dibandingkan dengan subyek yang memiliki aktivitas fisik sedang-tinggi hanya sebanyak 9 orang (9\%). Status gizi subyek menunjukkan bahwa sebagian besar subyek mempunyai status gizi lebih sebanyak 68 orang $(68 \%)$.

Ada hubungan pola konsumsi pangan sumber purin dengan kadar asam urat pada pra-lansia dan lansia di Puskesmas Kecamatan Makasar dan tidak terdapat hubungan antara Aktivitas Fisik dan Status Gizi pada Pra-lansia dan Lansia di Puskesmas Kecamatan Makasar.

\section{SARAN}

Bagi lansia yang memiliki status gizi lebih hendaknya menerapkan pola hidup sehat dengan cara makan makanan yang seimbang dan berolahraga secara teratur, sehingga dapat mencegah berbagai faktor resiko penyakit yang menyerang kesehatan tubuh, salah satunya akibat dari meningkatnya kadar asam urat. Bagi Puskesmas atau instansi terkait, untuk dapat dilakukannya upaya preventif dan promotif untuk pencegahan terjadinya penyakit asam urat yang kronis, mampu memberikan penyuluhan akan pentingnya pengontrolan kadar asam urat. Bagi masyarakat atau lansia agar dapat meningkatkan pola hidup yang sehat dengan mengkonsumsi makanan yang bergizi dan rendah purin serta rajin beraktifitas (olahraga). Dari hasil penelitian ini juga, diharapkan ada penelitian lanjutan untuk mengetahui faktor-faktor lain yang berpengaruh terhadap kadar asam urat dalam darah pada lansia.

\section{DAFTAR PUSTAKA}

Arpiana, I. 2017. Hubungan menopause dengan kadar asam urat dalam darah. Skripsi STIKES Insan Cendekia Medika, Jombang

Beavers KM, Hsu FC, Serra MC, Yank V, Pahor M, Nicklas BJ. 2014. The Effects of a Long-Term Physical Activity Intervention on Serum Uric Acid in Older Adults at Risk for Physical Disability. $J$ Aging Phys Act 22(2):25-33

Dayana B, Bahdrudin U. 2015. Hubungan Antara Intensitas Aktivitas Fisik Dan Kadar Asam Urat Serum Pada Populasi Sindrom Metabolik. Media Medika Muda 4(4).

Diantari E, Candra A. 2013. Pengaruh Asupan Purin Dan Cairan Terhadap Kadar Asam Urat Wanita Usia 50-60 Tahun Di Kecamatan Gajah Mungkur, Semarang. Journal of Nutrition College 2(1) 
Djokroprawiro, A, Setiawan B, Santoso D, Soegirto G. 2007. Buku Ajar Ilmu Penyakit Dalam. Airlangga University Press. Surabaya

Ilmiyati, L. 2017. Hubungan Asupan Purin, Vitamin C dan Status Gizi dengan Kadar Asam Urat pada Lansia di Posyandu Lansia Panjang Yuswo Kelurahan Panjang Kecamatan Laweyan Kota Surakarta [Skripsi]. Surakarta. Universitas Muhammadiyah Surakarta.

Fauzi M. 2018. Hubungan Aktivitas Fisik Dengan Kadar Asam Urat Di Padukuhan Bedog Trihanggo Gamping Sleman Yogyakarta. Naskah Publikasi Program Studi Ilmu Keperawatan, Fakultas Imu Kesehatan Universitas Aisyiyah.

[Kemenkes RI] Kementerian Kesehatan Republik Indonesia. 2014. Infofatin : Siatuasi dan Analisis Lanjut Usia. Pusat Data dan Informasi Kementerian Kesehatan.

[Kemenkes RI]. Kementrian Kesehatan Republik Indonesia. 2013a. Pedoman Pelayanan Gizi Lanjut Usia. Jakarta: Kementrian Kesehatan RI.

[Kemenkes RI]. Kementrian Kesehatan Republik Indonesia. 2013a. Pedoman Pelayanan Gizi Lanjut Usia. Jakarta: Kementrian Kesehatan RI.

Lingga, L. 2012. Bebas Penyak it Asam Urat Tanpa Obat. Jakarta: PT AgroMedia Pustaka.

Moriwaki, Y. 2014. Effects on Uric Acid Metabolism of the Drugs except the antihiperucemia. Journal of Bioequivalence and Bioavailability 6:1

Muhajir, NF, Widada, ST, Afuranto, B. 2014. Hubungan Antara Usia dengan Kadar Asam Urat Darah di Laboratorium Puskesmas Srimulyo, Triharjo, Sleman, Yogyakarta Tahun 2012. Jurnal Kesehatan Gubayo Vol 1 No 1.

Nursilmi. 2013. Hubungan Pola Konsumsi, Status Gizi, Dan Aktivitas Fisik Dengan Kadar Asam Urat Lansia Wanita Peserta Posbindu Sinarsari [Skripsi]. Bogor. Institut Petanian Bogor.

Pursriningsih SS, Panunggal B. 2015. Hubungan Asupan Purin, Vitamin C Dan Aktivitas Fisik Terhadap Kadar Asam Urat Pada Remaja Laki-Laki. Journal of Nutrition College 4(1).

Silviana H, Bintanah S, Isworo JT. 2015. Hubungan Status Gizi, Asupan Bahan Makan Sumber Purin dengan Kadar Asam Urat pada Pasien Hiperuresemia Rawat Jalan di Rumah Sakit Tugurejo Semarang. Universitas Muhammadiyah Semarang.

Sutanto T. 2013. Asam Urat : Deteksi, Pencegahan, Pengobatan. Yogyakarta: Buku Pintar.

Rosdiana SD, Khomsan A, Dwiriani CM. 2018. Pengetahuan Asam Urat, Asupan Purin Dan Status Gizi Terhadap Kejadian Hiperurisemia Pada Masyarakat Perdesaan. Media Pendidikan Gizi dan Kuliner 7(2).

Vita Health. 2004. Diabetes. Jakarta: PT. Gramedia Pustaka Utama. 
Williams PT. 2014. Effects of diet, physical activity and performance, and body weight on incident gout in ostensibly healthy, vigorously active men. Am J Clin Nutr. 2008;87:14801487.

Winarni, Y. 2016. Hubungan antara Indeks Massa Tubuh dengan Kadar Asam Urat dalam darah pada lanjut Usia di Puskesmas Paniki Bawah Kota Manado. Jurnal. Fakultas Kesehatan Msayarakat. Universitas Sam Ratulangi. Manado.

Yusfita LY 2018. Hubungan Perilaku Sedentari Dengan Sindrom Metabolik Pada Pekerja. The Indonesian Journal of Public Health, Vol 13, No 2 Desember 2018: 143-155 